\title{
System Study: Isolation Condenser 1998-2014
}

John A. Schroeder

December 2015

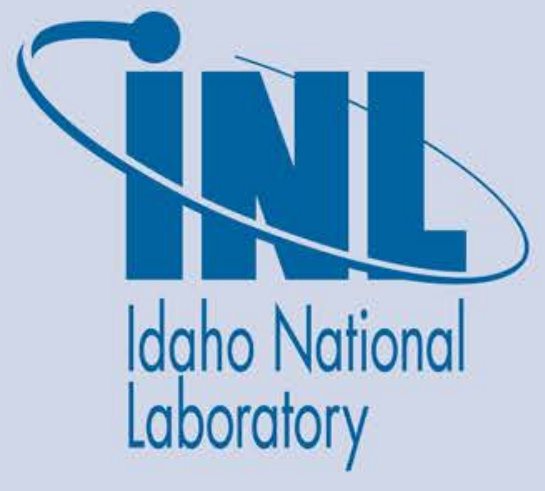

The INL is a U.S. Department of Energy National Laboratory operated by Battelle Energy Alliance 
NOTICE

This information was prepared as an account of work sponsored by an agency of the U.S. Government. Neither the U.S. Government nor any agency thereof, nor any of their employees, makes any warranty, express or implied, or assumes any legal liability or responsibility for any third party's use, or the results of such use, of any information, apparatus, product, or process disclosed herein, or represents that its use by such third party would not infringe privately owned rights. The views expressed herein are not necessarily those of the U.S. Nuclear Regulatory Commission. 


\title{
System Study: \\ Isolation Condenser \\ 1998-2014
}

\author{
John A. Schroeder
}

Update Completed December 2015

Idaho National Laboratory

Risk Assessment and Management Services Department Idaho Falls, Idaho 83415

http://www.inl.gov

Prepared for the

Division of Risk Assessment

Office of Nuclear Regulatory Research

U.S. Nuclear Regulatory Commission

NRC Agreement Number NRC-HQ-14-D-0018 



\begin{abstract}
This report presents an unreliability evaluation of the isolation condenser (ISO) system at four U.S. boiling water reactors. Demand, run hours, and failure data from fiscal year 1998 through 2014 for selected components were obtained from the Institute of Nuclear Power Operations (INPO) Consolidated Events Database (ICES). The unreliability results are trended for the most recent 10 -year period while yearly estimates for system unreliability are provided for the entire active period. No statistically significant increasing trends were identified. A statistically significant decreasing trend was identified for ISO unreliability. The magnitude of the trend indicated a 1.5 percent decrease in system unreliability over the last 10 years.
\end{abstract}


System Study

Isolation Condenser
2014 Update December 2015 


\section{CONTENTS}

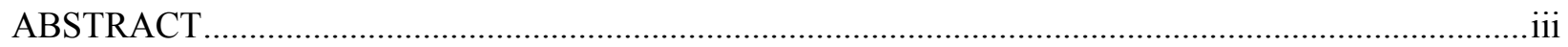

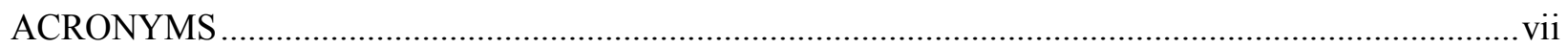

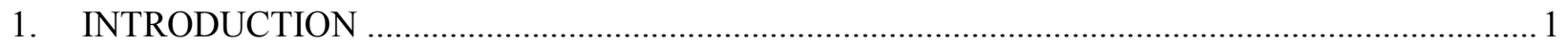

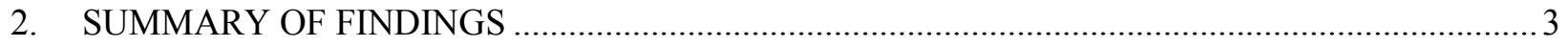

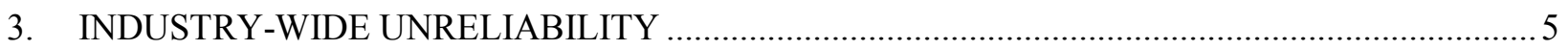

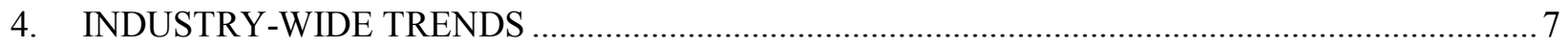

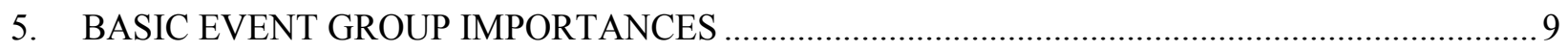

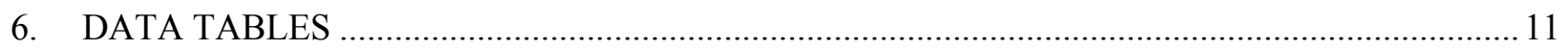

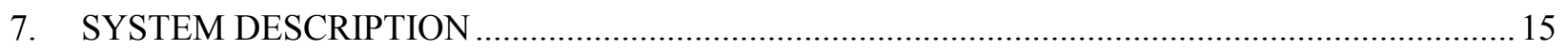

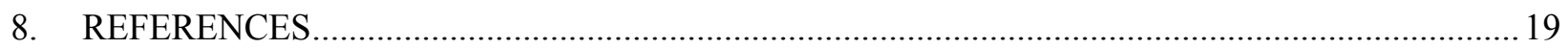

\section{FIGURES}

1. Trend of ISO system unreliability (operate and makeup), as a function of fiscal year........................ 7

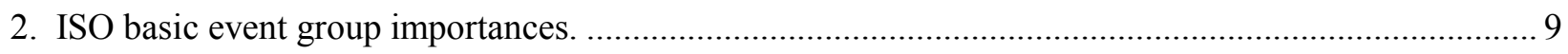

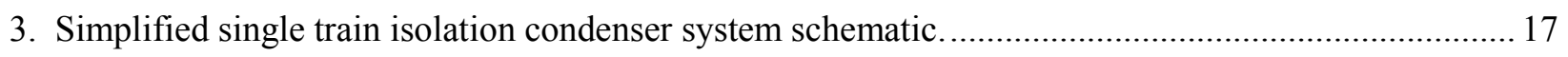

\section{TABLES}

1. BWR plants with an ISO system selected for the study............................................................ 1

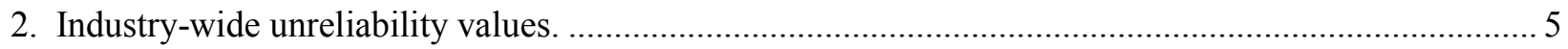

3. ISO model basic event importance group descriptions.............................................................. 9

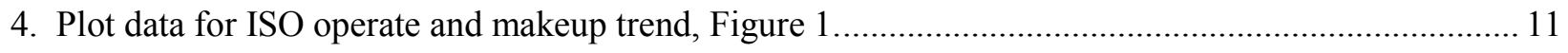

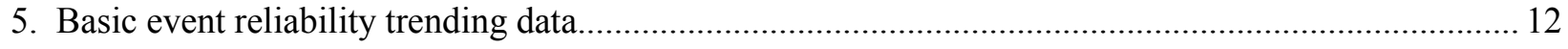




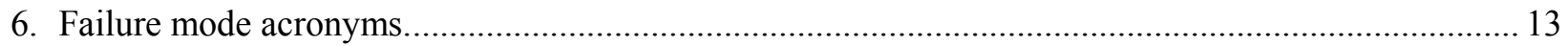

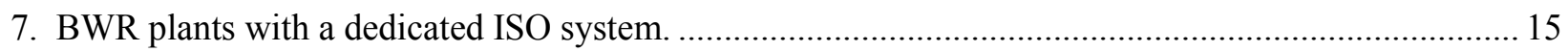




\section{ACRONYMS}

CCF common-cause failure

EPIX Equipment Performance and Information Exchange

FTOC fail to open/close

FTOP fail to operate

FY fiscal year

ICES INPO Consolidated Events Database

INPO Institute of Nuclear Power Operations

ISO isolation condenser

MSPI Mitigating Systems Performance Index

PRA probabilistic risk assessment

SO spurious operation

SPAR standardized plant analysis risk

SSU safety system unavailability 
System Study

Isolation Condenser
2014 Update December 2015 


\section{System Study: Isolation Condenser 1998-2014}

\section{INTRODUCTION}

This report presents an unreliability evaluation of the isolation condenser (ISO) system at 4 U.S. commercial boiling water reactors listed in Table 1. For each plant, the corresponding Standardized Plant Analysis Risk (SPAR) model (version model indicated in Table 1) was used in the yearly calculations. Demand, run hours, and failure data from fiscal year (FY)-98 through FY-14 for selected components in the ISO were obtained from the Institute of Nuclear Power Operations (INPO) Consolidated Events Database (ICES). Train unavailability data (outages from test or maintenance) were obtained from the Reactor Oversight Process Safety System Unavailability (SSU) database (FY-98 through FY-01) and the Mitigating Systems Performance Index (MSPI) database (FY-02 through FY-14). Common-cause failure (CCF) data used in the models are from the 2010 update to the CCF database. The system unreliability results are trended for the most recent 10-year period while yearly estimates for system unreliability are provided for the entire active period.

This report does not attempt to estimate basic event values for use in a probabilistic risk assessment (PRA). Suggested values for such use are presented in the 2010 Component Reliability Update (Reference 1), which is an update to Reference 2 (NUREG/CR-6928). Baseline ISO unreliability results using basic event values from that report are summarized in Section 3. Trend results for ISO (using system-specific data) are presented in Section 4. Similar to previous system study updates, Section 5 contains importance information (using the baseline results from Section 3), and Section 7 describes the ISO.

The ISO model is evaluated using the station blackout flag set in the SPAR model. The station blackout flag set assumes no support systems or normal sources of makeup water are available and that the ISO system is required to perform to mitigate the effects of the station blackout initiating event. All models include failures due to unavailability while in test or maintenance. Human error has not been included in the SPAR model logic. An overview of the trending methods, glossary of terms, and abbreviations can be found in the Overview and Reference document on the Reactor Operational Experience Results and Databases web page.

One mode of the models for the ISO system is calculated. The fail to operate (FTOP) model includes the initial opening of the condensate return valve and make-up capabilities to continue to operate for 8 hours.

Table 1. BWR plants with an ISO system selected for the study.

\begin{tabular}{lc}
\hline \multicolumn{1}{c}{ Plant } & Version \\
\hline Dresden 2 & 8.18 \\
Dresden 3 & 8.18 \\
Nine Mile Pt. 1 & 8.21 \\
Oyster Creek & 8.22 \\
\hline
\end{tabular}


System Study

Isolation Condenser
2014 Update

December 2015 


\section{SUMMARY OF FINDINGS}

The results of this ISO system unreliability study are summarized in this section. Of particular interest is the existence of any statistically significant ${ }^{\mathrm{a}}$ increasing trends. In this update, no statistically significant increasing trends were identified in the ISO unreliability trend results. A statistically significant decreasing trend was identified for ISO system unreliability. The magnitude of the trend indicates a 1.5 percent decrease in system unreliability over the most recent 10 years in the data set.

The industry-wide ISO 8-hour basic event group importance was evaluated and is shown in Figure 2. The leading contributor to ISO system unreliability is failure of the alternate source (only source of makeup water during a station blackout), followed by recovery, the condenser, a dependency on the EPS, and the ISO valves.

a. Statistically significant is defined in terms of the 'p-value.' A p-value is a probability indicating whether to accept or reject the null hypothesis that there is no trend in the data. P-values of less than or equal to 0.05 indicate that we are $95 \%$ confident that there is a trend in the data (reject the null hypothesis of no trend.) By convention, we use the "Michelin Guide" scale: p-value $<0.05$ (statistically significant), p-value $<0.01$ (highly statistically significant); pvalue $<0.001$ (extremely statistically significant). 
System Study

Isolation Condenser
2014 Update

December 2015 


\section{INDUSTRY-WIDE UNRELIABILITY}

The ISO fault trees from the SPAR models were evaluated for each of the 4 operating U.S. commercial boiling water nuclear power plants with an ISO system.

The industry-wide unreliability of the ISO system has been estimated for one mode of operation, failto-operate-and-makeup. The uncertainty distributions for ISO show both plant design variability and parameter uncertainty from the industry-wide component failure data (1998-2010)a.

Table 2 shows the percentiles and mean of the aggregated sample data (Latin hypercube, 1000 samples for each model) collected from the uncertainty calculations of the ISO fault trees in the SPAR models. The lower and upper bounds are based directly on the samples (Latin hypercube) from the uncertainty calculations in the SPAR models. For the industry-level results, the SPAR samples were combined into one large sample in order to determine the industry-level bounds, mean, and median.

Table 2. Industry-wide unreliability values.

\begin{tabular}{ccccc}
\hline Model & $\begin{array}{c}\text { Lower } \\
(\mathbf{5 \% )}\end{array}$ & Median & Mean & $\begin{array}{c}\text { Upper } \\
\mathbf{( 9 5 \% )}\end{array}$ \\
\hline Operate and makeup & $2.43 \mathrm{E}-05$ & $6.65 \mathrm{E}-03$ & $3.30 \mathrm{E}-02$ & $1.18 \mathrm{E}-01$ \\
\hline
\end{tabular}

a By using industry-wide component failure data, individual plant performance is not included in the distribution of results. 
System Study

Isolation Condenser
2014 Update December 2015 


\section{INDUSTRY-WIDE TRENDS}

The yearly (FY-98 through FY-14) failure and demand or run time data were obtained from ICES for the ISO system. The component basic event uncertainty was calculated for the ISO system components using the trending methods described in Section 1 and 2 of the Overview and Reference document. Table 5 shows the yearly data values for each ISO system specific component and failure mode combination that was varied in the model. These data were loaded into the ISO system fault tree in each SPAR model with an ISO system (see Table 1).

The trend charts show the results of varying component reliability data over time and updating generic, relatively-flat prior distributions using data for each year. In addition, for comparison, the calculated industry-wide system reliability from this update (current SPAR/ICES) is shown. Section 4 of the Overview and Reference link on the System Studies main web page provides more detailed discussion of the trending methods. In the lower left hand corner of the trend figures, the regression method is reported.

Figure 1 shows the trend in the system unreliability (operate and makeup). The trend is a statistically significant decreasing trend within the industry-wide estimates of ISO system unreliability (operate and makeup) on a per fiscal year basis. The observed trend represents a 1.5 percent decrease in system unreliability. Table 4 shows the data points for Figure 1.

The components that were varied in the ISO model are the ISO condensate MOV or AOV fail-toopen.

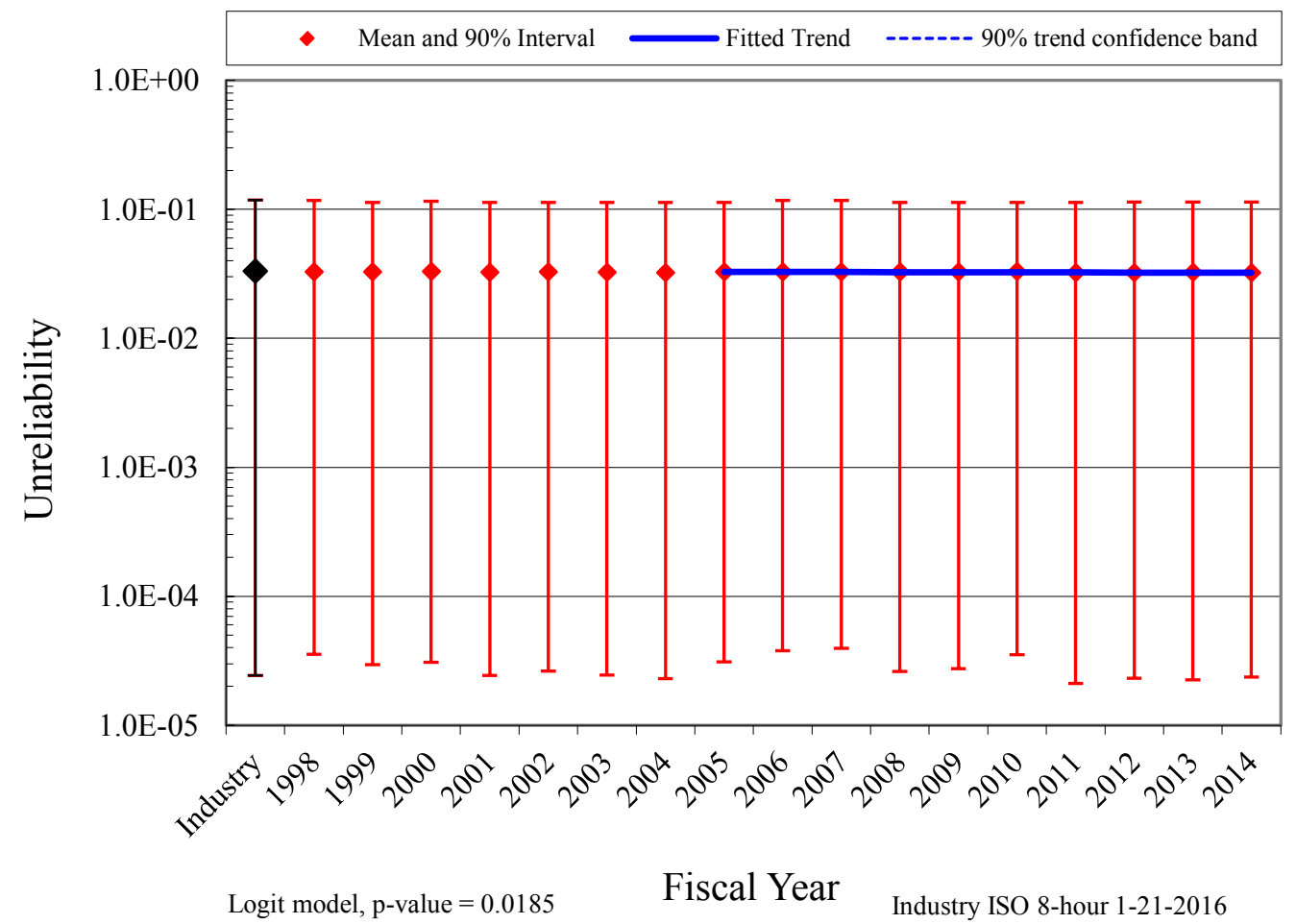

Figure 1. Trend of ISO system unreliability (operate and makeup), as a function of fiscal year. 
System Study

Isolation Condenser
2014 Update

December 2015 


\section{BASIC EVENT GROUP IMPORTANCES}

The ISO basic event group Fussell-Vesely importances were calculated for the operate and makeup mode for each plant using the industry-wide data (1998-2010). These basic event group importances were then averaged across all plants to represent an industry-wide basic event group importance.

The industry-wide ISO operate and makeup basic event group importances are shown in Figure 2. The leading contributors to ISO system unreliability are the isolation condenser heat exchanger, recovery and the ISO valves. For more discussion on the ISO valves, see the motor-operated and air-operated valve component reliability studies at NRC Reactor Operational Experience Results and Databases. Table 3 shows the SPAR model ISO importance groups and their descriptions.

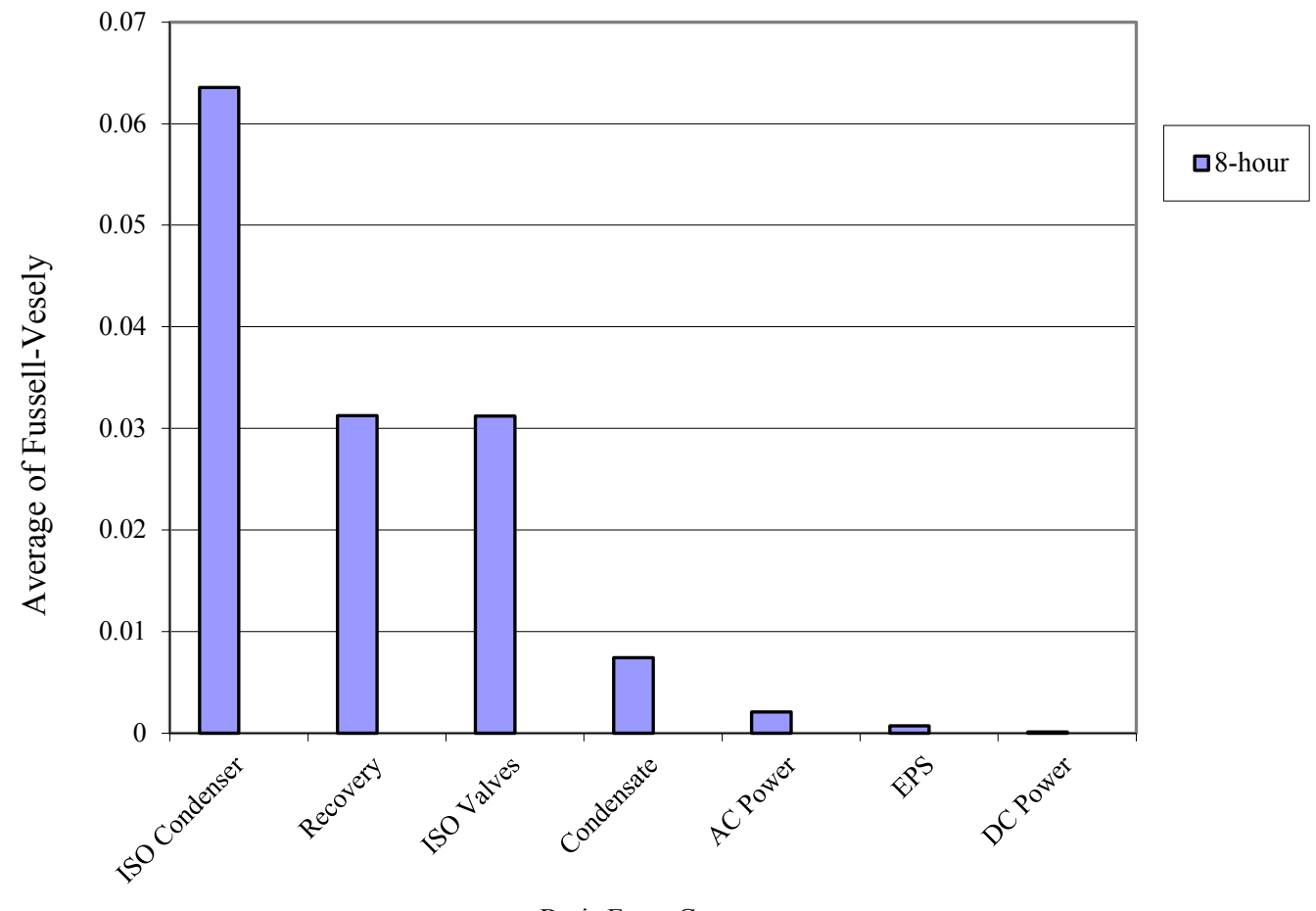

Basic Event Group

Figure 2. ISO basic event group importances.

Table 3. ISO model basic event importance group descriptions.

\begin{tabular}{|c|c|}
\hline Group & Description \\
\hline AC Power & $\begin{array}{l}\text { The ac buses and circuit breakers that supply power to the makeup water source } \\
\text { pumps and motor-operated valves if used. }\end{array}$ \\
\hline Condensate & $\begin{array}{l}\text { Normal source of cooling water to the isolation condenser includes pumps and } \\
\text { valves. }\end{array}$ \\
\hline DC Power & The batteries and battery chargers that supply power to the ISO circuitry and valves. \\
\hline EPS & Emergency power system dependency. \\
\hline ISO Condenser & The isolation condenser heat exchanger. \\
\hline ISO Valves & Air or motor-operated valves required for the isolation condenser function. \\
\hline Recovery & Recovery from failure to actuate. \\
\hline
\end{tabular}


System Study

Isolation Condenser
2014 Update

December 2015 


\section{DATA TABLES}

Table 4. Plot data for ISO operate and makeup trend, Figure 1.

\begin{tabular}{ccccccc}
\hline & \multicolumn{2}{c}{ Regression Curve Data Points } & \multicolumn{2}{c}{ Annual Estimate Data Points } \\
\cline { 2 - 6 } FY/Source & Mean & $\begin{array}{c}\text { Lower } \\
\mathbf{( 5 \% )}\end{array}$ & $\begin{array}{c}\text { Upper } \\
\mathbf{( 9 5 \% )}\end{array}$ & $\begin{array}{c}\text { Lower } \\
\mathbf{( 5 \% )}\end{array}$ & $\begin{array}{c}\text { Upper } \\
\mathbf{( 9 5 \% )}\end{array}$ & Mean \\
\hline SPAR/ICES & & & & $2.43 \mathrm{E}-05$ & $1.18 \mathrm{E}-01$ & $3.30 \mathrm{E}-02$ \\
1998 & & & & $3.54 \mathrm{E}-05$ & $1.17 \mathrm{E}-01$ & $3.25 \mathrm{E}-02$ \\
1999 & & & & $2.94 \mathrm{E}-05$ & $1.13 \mathrm{E}-01$ & $3.27 \mathrm{E}-02$ \\
\hline 2000 & & & & $3.07 \mathrm{E}-05$ & $1.16 \mathrm{E}-01$ & $3.28 \mathrm{E}-02$ \\
\hline 2001 & & & & $2.43 \mathrm{E}-05$ & $1.14 \mathrm{E}-01$ & $3.23 \mathrm{E}-02$ \\
\hline 2002 & & & & $2.62 \mathrm{E}-05$ & $1.13 \mathrm{E}-01$ & $3.26 \mathrm{E}-02$ \\
\hline 2003 & & & & $2.45 \mathrm{E}-05$ & $1.14 \mathrm{E}-01$ & $3.23 \mathrm{E}-02$ \\
\hline 2004 & & & & $2.30 \mathrm{E}-05$ & $1.13 \mathrm{E}-01$ & $3.22 \mathrm{E}-02$ \\
\hline 2005 & $3.28 \mathrm{E}-02$ & $3.25 \mathrm{E}-02$ & $3.31 \mathrm{E}-02$ & $3.11 \mathrm{E}-05$ & $1.13 \mathrm{E}-01$ & $3.27 \mathrm{E}-02$ \\
\hline 2006 & $3.27 \mathrm{E}-02$ & $3.25 \mathrm{E}-02$ & $3.30 \mathrm{E}-02$ & $3.78 \mathrm{E}-05$ & $1.17 \mathrm{E}-01$ & $3.26 \mathrm{E}-02$ \\
\hline 2007 & $3.27 \mathrm{E}-02$ & $3.25 \mathrm{E}-02$ & $3.29 \mathrm{E}-02$ & $3.96 \mathrm{E}-05$ & $1.17 \mathrm{E}-01$ & $3.26 \mathrm{E}-02$ \\
2008 & $3.26 \mathrm{E}-02$ & $3.24 \mathrm{E}-02$ & $3.28 \mathrm{E}-02$ & $2.62 \mathrm{E}-05$ & $1.13 \mathrm{E}-01$ & $3.27 \mathrm{E}-02$ \\
\hline 2009 & $3.26 \mathrm{E}-02$ & $3.24 \mathrm{E}-02$ & $3.27 \mathrm{E}-02$ & $2.74 \mathrm{E}-05$ & $1.13 \mathrm{E}-01$ & $3.27 \mathrm{E}-02$ \\
\hline 2010 & $3.25 \mathrm{E}-02$ & $3.24 \mathrm{E}-02$ & $3.26 \mathrm{E}-02$ & $3.52 \mathrm{E}-05$ & $1.13 \mathrm{E}-01$ & $3.28 \mathrm{E}-02$ \\
\hline 2011 & $3.24 \mathrm{E}-02$ & $3.23 \mathrm{E}-02$ & $3.26 \mathrm{E}-02$ & $2.11 \mathrm{E}-05$ & $1.14 \mathrm{E}-01$ & $3.22 \mathrm{E}-02$ \\
\hline 2012 & $3.24 \mathrm{E}-02$ & $3.22 \mathrm{E}-02$ & $3.26 \mathrm{E}-02$ & $2.32 \mathrm{E}-05$ & $1.14 \mathrm{E}-01$ & $3.22 \mathrm{E}-02$ \\
\hline 2013 & $3.23 \mathrm{E}-02$ & $3.21 \mathrm{E}-02$ & $3.26 \mathrm{E}-02$ & $2.24 \mathrm{E}-05$ & $1.14 \mathrm{E}-01$ & $3.24 \mathrm{E}-02$ \\
\hline 2014 & $3.23 \mathrm{E}-02$ & $3.20 \mathrm{E}-02$ & $3.26 \mathrm{E}-02$ & $2.36 \mathrm{E}-05$ & $1.14 \mathrm{E}-01$ & $3.22 \mathrm{E}-02$ \\
\hline
\end{tabular}


Table 5. Basic event reliability trending data.

\begin{tabular}{|c|c|c|c|c|c|c|c|c|}
\hline \multirow{2}{*}{$\begin{array}{l}\text { Failure } \\
\text { Mode }\end{array}$} & \multirow[b]{2}{*}{ Component } & \multirow[b]{2}{*}{ Year } & \multirow{2}{*}{$\begin{array}{l}\text { Number of } \\
\text { Failures }\end{array}$} & \multirow{2}{*}{$\begin{array}{l}\text { Demands/ } \\
\text { Run Hours }\end{array}$} & \multicolumn{4}{|c|}{ Bayesian Update } \\
\hline & & & & & Mean & Post A & Post B & Distribution \\
\hline FTOC & AOV & 1998 & 0 & 39.56 & $9.20 \mathrm{E}-04$ & 1.112 & 1207.56 & Beta \\
\hline FTOC & AOV & 1999 & 0 & 40.06 & $9.20 \mathrm{E}-04$ & 1.112 & 1208.06 & Beta \\
\hline FTOC & AOV & 2000 & 0 & 42.06 & $9.18 E-04$ & 1.112 & 1210.06 & Beta \\
\hline FTOC & AOV & 2001 & 0 & 42.06 & $9.18 E-04$ & 1.112 & 1210.06 & Beta \\
\hline FTOC & AOV & 2002 & 0 & 40.02 & $9.20 \mathrm{E}-04$ & 1.112 & 1208.02 & Beta \\
\hline FTOC & AOV & 2003 & 0 & 66.87 & 9.00E-04 & 1.112 & 1234.87 & Beta \\
\hline FTOC & AOV & 2004 & 0 & 50.82 & $9.12 \mathrm{E}-04$ & 1.112 & 1218.82 & Beta \\
\hline FTOC & AOV & 2005 & 0 & 60.3 & 9.04E-04 & 1.112 & 1228.3 & Beta \\
\hline FTOC & AOV & 2006 & 0 & 40.6 & 9.19E-04 & 1.112 & 1208.6 & Beta \\
\hline FTOC & AOV & 2007 & 0 & 50.64 & $9.12 \mathrm{E}-04$ & 1.112 & 1218.64 & Beta \\
\hline FTOC & AOV & 2008 & 0 & 49.64 & $9.12 \mathrm{E}-04$ & 1.112 & 1217.64 & Beta \\
\hline FTOC & AOV & 2009 & 0 & 66.64 & 9.00E-04 & 1.112 & 1234.64 & Beta \\
\hline FTOC & AOV & 2010 & 0 & 49.64 & 9.12E-04 & 1.112 & 1217.64 & Beta \\
\hline FTOC & AOV & 2011 & 0 & 52.64 & 9.10E-04 & 1.112 & 1220.64 & Beta \\
\hline FTOC & AOV & 2012 & 0 & 45.64 & $9.15 \mathrm{E}-04$ & 1.112 & 1213.64 & Beta \\
\hline FTOC & AOV & 2013 & 0 & 65.64 & 9.01E-04 & 1.112 & 1233.64 & Beta \\
\hline FTOC & AOV & 2014 & 0 & 41.64 & 9.18E-04 & 1.112 & 1209.64 & Beta \\
\hline FTOP & AOV & 1998 & 0 & 52560 & 2.46E-07 & 1.421 & 5771560 & Gamma \\
\hline FTOP & AOV & 1999 & 0 & 52560 & 2.46E-07 & 1.421 & 5771560 & Gamma \\
\hline FTOP & AOV & 2000 & 0 & 52560 & 2.46E-07 & 1.421 & 5771560 & Gamma \\
\hline FTOP & AOV & 2001 & 0 & 52560 & 2.46E-07 & 1.421 & 5771560 & Gamma \\
\hline FTOP & AOV & 2002 & 1 & 52560 & 4.19E-07 & 2.421 & 5771560 & Gamma \\
\hline FTOP & AOV & 2003 & 0 & 52560 & 2.46E-07 & 1.421 & 5771560 & Gamma \\
\hline FTOP & AOV & 2004 & 0 & 52560 & 2.46E-07 & 1.421 & 5771560 & Gamma \\
\hline FTOP & AOV & 2005 & 0 & 52560 & 2.46E-07 & 1.421 & 5771560 & Gamma \\
\hline FTOP & AOV & 2006 & 0 & 52560 & 2.46E-07 & 1.421 & 5771560 & Gamma \\
\hline FTOP & AOV & 2007 & 0 & 52560 & 2.46E-07 & 1.421 & 5771560 & Gamma \\
\hline FTOP & AOV & 2008 & 0 & 52560 & 2.46E-07 & 1.421 & 5771560 & Gamma \\
\hline FTOP & AOV & 2009 & 0 & 52560 & 2.46E-07 & 1.421 & 5771560 & Gamma \\
\hline FTOP & AOV & 2010 & 0 & 52560 & 2.46E-07 & 1.421 & 5771560 & Gamma \\
\hline FTOP & AOV & 2011 & 0 & 52560 & 2.46E-07 & 1.421 & 5771560 & Gamma \\
\hline FTOP & AOV & 2012 & 0 & 52560 & 2.46E-07 & 1.421 & 5771560 & Gamma \\
\hline FTOP & AOV & 2013 & 0 & 52560 & 2.46E-07 & 1.421 & 5771560 & Gamma \\
\hline FTOP & AOV & 2014 & 0 & 52560 & 2.46E-07 & 1.421 & 5771560 & Gamma \\
\hline so & AOV & 1998 & 0 & 52560 & 1.29E-07 & 0.6801 & 5263560 & Gamma \\
\hline SO & AOV & 1999 & 0 & 52560 & 1.29E-07 & 0.6801 & 5263560 & Gamma \\
\hline so & AOV & 2000 & 0 & 52560 & 1.29E-07 & 0.6801 & 5263560 & Gamma \\
\hline SO & AOV & 2001 & 0 & 52560 & 1.29E-07 & 0.6801 & 5263560 & Gamma \\
\hline so & AOV & 2002 & 0 & 52560 & 1.29E-07 & 0.6801 & 5263560 & Gamma \\
\hline SO & AOV & 2003 & 0 & 52560 & 1.29E-07 & 0.6801 & 5263560 & Gamma \\
\hline so & AOV & 2004 & 0 & 52560 & 1.29E-07 & 0.6801 & 5263560 & Gamma \\
\hline
\end{tabular}


Table 5. (continued).

\begin{tabular}{ccccccccc}
\hline \multirow{2}{*}{$\begin{array}{c}\text { Failure } \\
\text { Mode }\end{array}$} & Component & Year & $\begin{array}{c}\text { Number of } \\
\text { Failures }\end{array}$ & $\begin{array}{c}\text { Demands/ } \\
\text { Run Hours }\end{array}$ & Mean & Post A & Post B & Distribution \\
\hline SO & AOV & 2005 & 0 & 52560 & $1.29 \mathrm{E}-07$ & 0.6801 & 5263560 & Gamma \\
SO & AOV & 2006 & 0 & 52560 & $1.29 \mathrm{E}-07$ & 0.6801 & 5263560 & Gamma \\
SO & AOV & 2007 & 0 & 52560 & $1.29 \mathrm{E}-07$ & 0.6801 & 5263560 & Gamma \\
SO & AOV & 2008 & 0 & 52560 & $1.29 \mathrm{E}-07$ & 0.6801 & 5263560 & Gamma \\
SO & AOV & 2009 & 0 & 52560 & $1.29 \mathrm{E}-07$ & 0.6801 & 5263560 & Gamma \\
SO & AOV & 2010 & 0 & 52560 & $1.29 \mathrm{E}-07$ & 0.6801 & 5263560 & Gamma \\
SO & AOV & 2011 & 0 & 52560 & $1.29 \mathrm{E}-07$ & 0.6801 & 5263560 & Gamma \\
SO & AOV & 2012 & 0 & 52560 & $1.29 \mathrm{E}-07$ & 0.6801 & 5263560 & Gamma \\
SO & AOV & 2013 & 0 & 52560 & $1.29 \mathrm{E}-07$ & 0.6801 & 5263560 & Gamma \\
SO & AOV & 2014 & 0 & 52560 & $1.29 \mathrm{E}-07$ & 0.6801 & 5263560 & Gamma \\
\hline
\end{tabular}

Table 6. Failure mode acronyms.

\begin{tabular}{ll}
\hline \multicolumn{1}{c}{ Failure Mode } & \multicolumn{1}{c}{ Failure Mode Description } \\
\hline FTOC & Fail to open/close \\
FTOP & Fail to operate \\
SO & Spurious operation \\
\hline
\end{tabular}


System Study

Isolation Condenser
2014 Update

December 2015 


\section{SYSTEM DESCRIPTION}

This analysis focused on the ability of the ISO system to start and provide design-rated core cooling for its required mission time.

The models used in this report are limited to the models that represent the set of plants listed in Table 1. This analysis focused only on the isolation condenser's emergency core cooling system function to reduce reactor pressure and remove fission product decay heat. The containment isolation function of the system was not evaluated in this study.

Table 7. BWR plants with a dedicated ISO system.

\begin{tabular}{|c|c|c|c|c|c|c|}
\hline Plant Name & Docket & Trains & $\begin{array}{l}\text { Total Number } \\
\text { of ISO } \\
\text { Condensers }\end{array}$ & $\begin{array}{c}\text { Number of } \\
\text { Condensers } \\
\text { per Train }\end{array}$ & $\begin{array}{c}\text { Condenser } \\
\text { Design }\end{array}$ & $\begin{array}{c}\text { Time Before Make- } \\
\text { up is Required } \\
\text { (min) }\end{array}$ \\
\hline Dresden 2 & 237 & 1 & 1 & 1 & Dual-pass & 20 \\
\hline Dresden 3 & 249 & 1 & 1 & 1 & Dual-pass & 20 \\
\hline Millstone $1^{\mathrm{a}}$ & 245 & 1 & 1 & 1 & Dual-pass & 30 \\
\hline Nine Mile Pt. 1 & 220 & 2 & 4 & 2 & Single-pass & 90 \\
\hline Oyster Creek & 219 & 2 & 2 & 1 & Dual-pass & 45 \\
\hline
\end{tabular}

The ISO system is a standby high-pressure system that removes residual and decay heat from the reactor vessel in the event of a scram in which the reactor becomes isolated from the main condenser, or if any other high pressure condition exists. Also, at most plants, the ISO system aids in reactor vessel depressurization in the event that either (depending on plant design) the feedwater coolant injection or high-pressure coolant injection system fails. Because of its role in emergency core cooling, the ISO system is designated as an emergency core cooling system. The ISO system is a single-train system in three plants and dual-train system in the other two plants.

Figure 3 provides a simplified single train ISO system diagram. This configuration is typical of the single train plants and is effectively doubled for the dual-train plants. Four plants have a single dual-pass isolation condenser per train, while one plant (Nine Mile Pt. 1) has two single-pass isolation condensers per train.

The ISO system transfers residual and decay heat from the reactor coolant to the water in the shell side of the heat exchanger resulting in steam generation. The steam generated in the shell side of the heat exchanger is then vented to the outside atmosphere. The system employs natural circulation as the driving head from the reactor steam side, through the isolation condenser tubes, and back to the reactor.

A typical ISO system is designed to handle three percent reactor power, which means that five minutes after a scram and initiation of the ISO system, the heat removal capacity of the system equals the decay heat production rate of the shutdown reactor. Therefore, reactor water inventory will only be lost through the relief valves for five minutes following a scram and isolation. This represents a minor loss relative to the vessel inventory.

The ISO system is typically required to be operable when there is fuel in the reactor vessel and steam is being produced. During normal operation the isolation condensers are in standby, and are placed in service automatically when needed to provide heat transfer to the environment. In the stand-by condition, the steam isolation valves are open so that the condenser tube bundles are at reactor pressure. Condensate builds up in the condenser and condensate return piping; the condensate is prevented from returning to the reactor by having one of the condensate return valves for that train closed. The steam lines contain vent 
valves, which are open to vent air and noncondensibles to the main steam system. Collection of air or noncondensible gases in the ISO system could prevent natural circulation flow. The initiation signal places the ISO system into operation by opening the condensate return isolation valve. This valve can also be remotely operated from the control room.

The ISO system operates in a closed loop mode. Steam rises from the reactor vessel to the condenser where it is condensed by boiling the water in the condenser shell. As the reactor steam condenses, it returns by gravity flow through the condensate return valve to the suction of a reactor recirculation pump and thus to the reactor vessel. The water inventory on the shell side of the condenser will provide heat removal for between 20 and 90 minutes depending on the plant design, at which time makeup water must be provided to prevent uncovering the condenser tubes. The sources of makeup water are a combination of condensate water, demineralized water, or the fire water system depending on individual plant design. One plant (Nine Mile Pt. 1) has gravity fed makeup water tanks, which can supply enough water for eight hours of operation before additional makeup is required.

The ISO system instrumentation and control consists of initiation and containment isolation circuitry. These circuits provide different functions, both of which are important to system reliability. The initiation circuitry provides for automatic and manual start of the system. The purpose of the containment isolation circuitry is to initiate closure of appropriate primary containment isolation valves to limit fission product release should a steam line rupture occur.

The ISO system is automatically initiated if a high reactor pressure condition is sustained for 15 seconds. The time delay prevents unnecessary system initiation during turbine trips. Also at most plants, the ISO system automatically initiates on a low vessel water level to aid in reducing reactor pressure for small line breaks. The isolation condenser system can be operated manually by opening the condensate return valve. The ISO system is designed to provide core cooling regardless of whether electrical power is available.

The ISO system is automatically isolated if high ISO steam flow or condensate return flow is sensed indicating a line break (Group V isolation). This isolation shuts all the steam and condensate isolation valves and the steam line vent valves, rendering the ISO system inoperable. The steam line vent valves will also automatically shut on a low vessel water level condition (Group I isolation). Isolation of the vent valves for a prolonged period could render the heat exchanger inoperable due to the buildup of noncondensable gases. However, failure of this circuit to close the vent valves would not preclude operation of the system. 


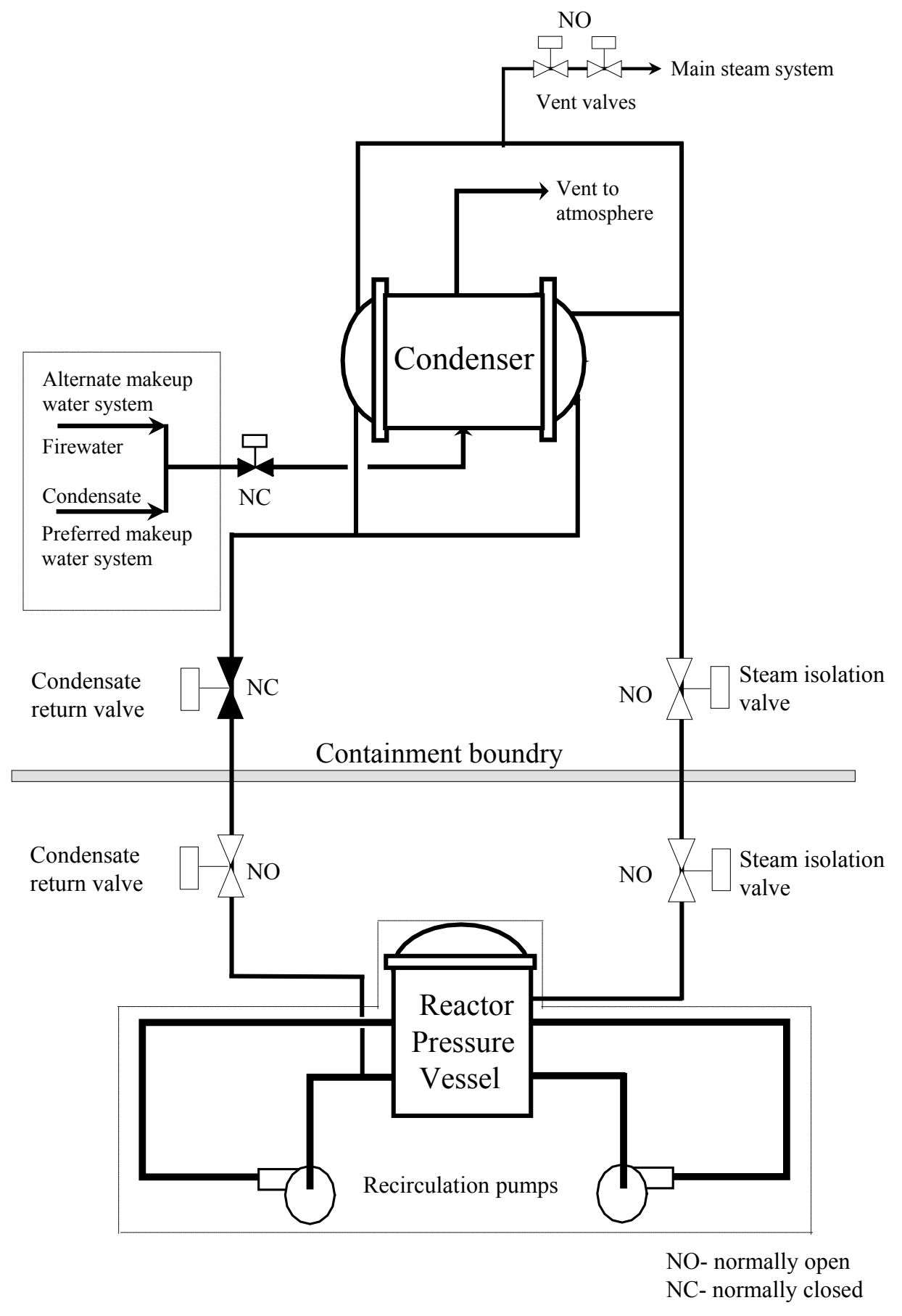

Outside system boundary

Figure 3. Simplified single train isolation condenser system schematic. 
System Study

Isolation Condenser
2014 Update

December 2015 


\section{REFERENCES}

1. Nuclear Regulatory Commission, Component Reliability Data Sheets Update 2010, January 2012, http://nrcoe.inl.gov/resultsdb/publicdocs/AvgPerf/ComponentReliabilityDataSheets2010.pdf

2. S.A. Eide et al., Industry-Average Performance for Components and Initiating Events at U.S. Commercial Nuclear Power Plants, Nuclear Regulatory Commission, NUREG/CR-6928, February 2007. 